\title{
Excursions
}

Volume 6, Issue 1 (December 2015) Occupations

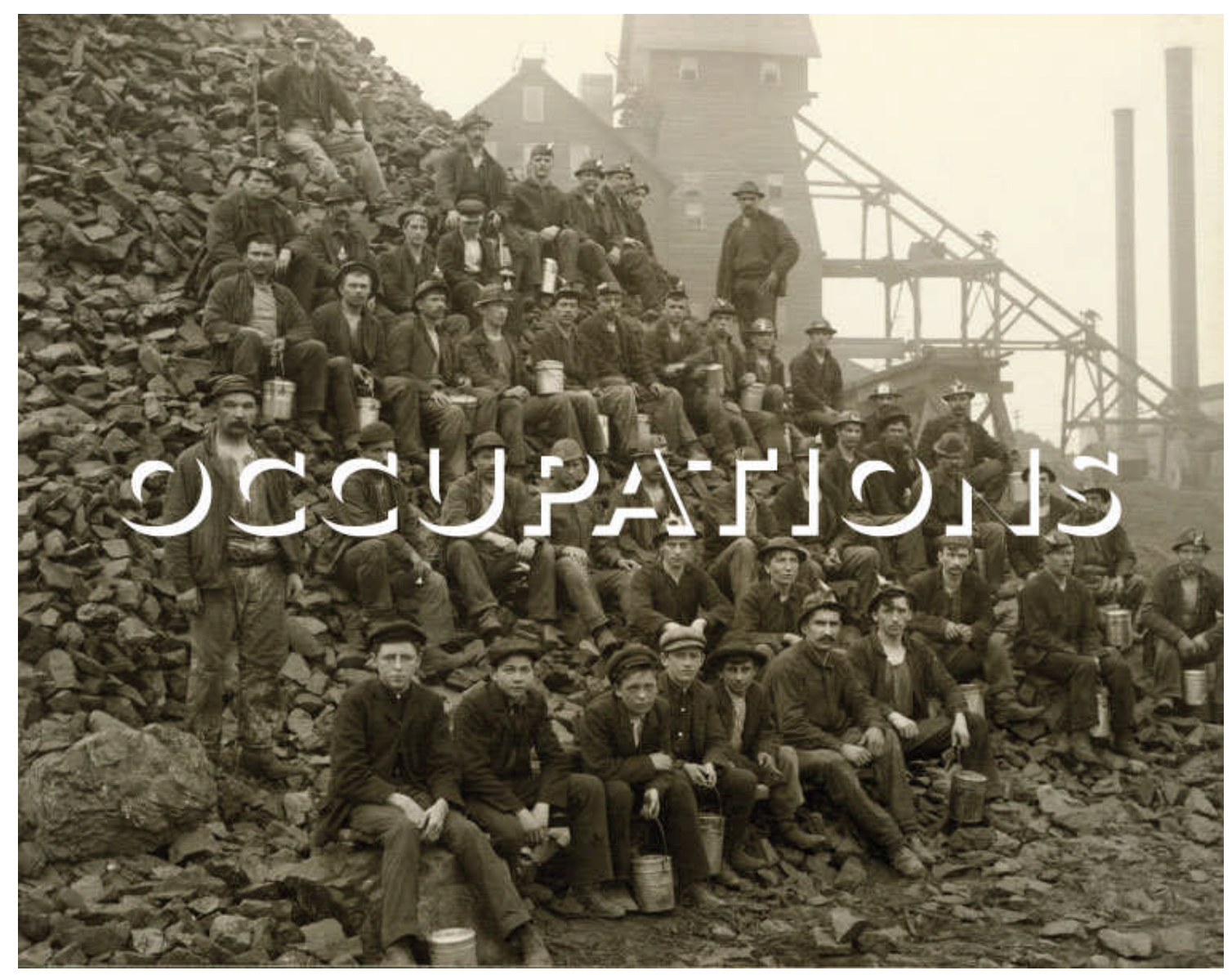

Cover photo: Justin McIntosh Cover design: Danny Bright

Patricia Sequeira Brás, 'How not to Occupy Bartleby’

Excursions, vol. 6, no. 1 (2015) 
Patricia Sequeira Brás

Queen Mary, University of London

\section{How not to Occupy Bartleby}

This article discusses how Bartleby, Herman Melville's literary character from the homonymous story, Bartleby, The Scrivener, re-emerged in the Occupy Movement in Wall Street. It intends to argue that Melville's story has been wrongly appropriated, because Bartleby's occupation of the physical space of the lawyer's Wall Street office is not a symbolic act. Instead, Bartleby's formula should be recognised as the initial gesture towards emancipation. This is so because Bartleby's formula offers a space for social contingency as it suggests the withdrawal from social order. Rather than attempting to find some political agency in Melville's figure, this article aims to recognise the capacity of Bartleby's formula for political insurgency. In this way, it seeks to revise Occupy Wall Street's (OWS's) appropriation of, and relation to, Melville's short story, as well as suggesting that Bartleby's formula offers an embodiment of political contingency rather than the means to a political outcome.

This response attempts to reassess the numerous articles relating the Occupy Movement to Melville’s Bartleby during the protests of 2011 and 2012 (Asher, 2013; 
Greenberg, 2012; Klein, 2011; Martyris, 2011; Yin, 2011). Within the context of ongoing protests and acts of occupation that continue across the globe, Bartleby's significance needs to be re-articulated and re-examined, beyond his employ as an ally and precursor to OWS's actions in New York City. In 2014, we saw sit-ins and the student occupation of many university campuses in the UK, following the violent actions of the police force in response to the demonstration at Warwick University; Hong Kong protests, known as the Umbrella Revolution, organized by Occupy Central with Love and Peace; Occupy Democracy in London; but also, the protests in Brazil during the football World Cup and Ferguson protests in Missouri and other states in the USA, following the shooting of Michael Brown, and the consequent discharge of police officer Darren Wilson for Brown's death, which I choose to mention, despite this not being directly related to the Occupy movement. In 2015, we have already witnessed the protests of Occupy Democracy in Parliament Square in London and the occupation of a Golf course in the 'up market' neighbourhood of Barra da Tijuca, Brazil, built on an environmentally protected area to serve the 2016 Olympic games in Rio de Janeiro (Douglas, 2015). All these protests prove that the original occupy movement did not run out of steam but instead has become a systemic form of protest. In light of this, there is renewed importance in a revaluation of Bartleby's formula within the context of what some have called the 'Age of Occupy' (Asher, 2013).

In Melville's story, Bartleby is a clerk who passively refuses to proofread, and then to copy legal documents by insistently replying: 'I would prefer not to'. Bartleby is expected to copy documents and attend to diverse office chores but his gesture of passive refusal suspends the social and economic function ascribed to him. Instead of vehemently rejecting the tasks or denying his role, Bartleby prefers not to copy. But what he prefers to do remains undisclosed. His 'formula', as described by Gilles Deleuze, consists neither of an affirmation nor a negation. Bartleby does not leave the premises of the lawyer's office but without maintaining his professional utility, his passivity is an affront to what is expected of him. For that reason, I argue that his formula exposes the mechanics of social (re)-production. This, in turn, is understood as political.

The OWS movement revitalised Melville's literary character in a strongly literal fashion. OWS both physically paralleled Bartleby's occupation of the lawyer's Wall Street office through its symbolic occupation of Zucotti Park, as well as corresponding Bartleby's 'nonpreference' with the movement's refusal to formulate a single defined demand. According to Russ Castronovo, OWS's appropriation of Bartleby is based on a formal analogy (2014, p.253). This is so because 'the activists at Occupy Wall Street who became readers of Melville invoked literature for its demonstrative power as an analogy, not for its enigmatic qualities that solicit interpretation' (Castronovo, 2014, p.259). This analogy, as Castronovo argues, follows a 'logic of resemblance [that] uncovers deep and perhaps unexpected affinities 
among those who dare to prefer something other than the standard remedies proposed at a time of crisis' (2014, p.267). In this way, analogy functions to build a relationship between different terms and/or different people, in search for a commonality. In relation to the movement's lack of demands, Castronovo insists that this was so because OWS 'preferred not to participate in the normative political processes in which reforms are granted only insofar as they keep the status quo intact' (2014, p.263). Like Bartleby's formula, the demands of the Occupy movement disregard any 'positive content' (Castronovo, 2014, p.265). This is the reason why the movement can be considered to be inefficient: it refuses to make one single demand.

In November 2011, it was reported that a group from the Occupy Wall Street movement staged a reading of Melville's Bartleby, the Scrivener at Zuccotti Park (Yin, 2011). This act, as already mentioned, provoked many to establish a direct relation between Melville's literary character and OWS. For those, Bartleby is to be regarded as 'slacktivist'; an example of 'capitalism's most loathed object' that, by excluding 'himself out of the system, [...] preempts his own irrelevance' (Martyris, 2011). Others argue that the 'greatest power' of OWS was not to propose a single demand just as Bartleby does not disclose what he prefers to do (Greenberg, 2012); or that Bartleby's ‘I would prefer not to’ obliges us to rethink possibilities of resistance (Klein, 2011).

The Occupy Movement has then offered an alternative political discourse without proposing a single demand. It had a great impact on and in society, providing a discourse that attempted to 'represent' the $99 \%$ of the world's population against the $1 \%$ that owns the world's wealth, and also introducing the word 'occupy' to our daily lives. This can be understood as a change in what Rancière calls the 'sensible wealth' as the result of a disruption between sense and senses, and senses and thought to generate new possibilities for political activism (2004b; 2008; 2010). The organization of bodies, things, senses and thoughts corresponds to the 'distribution of the sensible', or to what Rancière identifies as the police rather than politics. Politics, on the other hand, happens when this distribution is disrupted, resulting in the redistribution of the sensible wealth, when bodies and things, senses and thoughts no longer correspond to their previous understanding. My argument is that OWS contributed to this disruption, and as such, can be accountable as political and not entirely inconsequential. In this way, it is also possible to parallel Bartleby's formula and OWS's alternative political discourse. As mentioned before, Bartleby's formula neither affirms nor negates, it leaves what it rejects undetermined; in the same fashion, OWS refuses to partake in 'normative political processes' by not proposing a single demand. Both positions are political but deprived of a defined political outcome.

Levi Bryant's critique of OWS concerns itself not so much with the movement's inability to propose a demand, but finds fault rather in its seemingly exclusive foundation upon a 
'cultural and ideological critique of Capitalism' (2011). For him, the movement did not seem to offer 'political efficacy' because 'they simply tarry at the level of signs and discourses, ignoring the material infrastructure upon which this form of production relies to perpetuate, continue, and sustain itself' (2011). These occupations seemed to occur everywhere, apart from 'the places where they would have a chance to make a real difference and produce real results' (2011). In this respect, Bryant explains that, 'if we think of capitalist social systems as being akin to an organic body, then these social systems will have a circulatory system and a nervous system' (2011). On the one hand, the nervous system consists of 'the various mediums through which information is transmitted'; whilst the circulatory system corresponds to 'the various paths of distribution and production the system requires to produce this sort of social structure such as highways, trains, airports, portions of the internet used for monetary exchange, farms, shipping lanes, etc' (2011). According to Bryant, the movement could have become politically effective against capitalism if it had provoked a 'stroke or a heart attack' within the capitalist system (2011). Rather than the symbolic occupation of a park, Bryant insists that OWS should have occupied the highways, ports (as in the case of Oakland) and internet: spaces in which monetary transactions are made. For him, the attention on 'the nervous system' rather seems to generate 'a form of political engagement that is merely one more form of information production leaving the basic structure of the system intact' (2011).

The protests seen in shopping centres during Black Friday in St. Louis, Missouri in 2014 can be understood as attempting to hit the circulatory system rather than the nervous system of capitalism, and as partial fulfilments of Bryant's desire to see the occupation of transactional space. These demonstrations, in response to the aforementioned killing of Michael Brown and the subsequent discharge of the police officer that killed him, resulted in the shutting down of shopping centres and people being prevented from shopping (Gambino, 2014). Despite only being temporary, these protests managed to bring local consumerism to a standstill.

I agree with Bryant in the sense that if one's aim is political efficacy, then one should occupy not so much a symbolic space but instead the spaces that permit the distribution that is required for the reproduction of the system. That is to say, one should not occupy what Bryant identifies as the nervous system of capitalism so much as what he defines as its circulatory system. However, the reproduction of the capitalist system is also possible through symbolic means. For this reason, it is important to re-interpret Bartleby's formula because Melville's character does not merely occupy the physical space of the lawyer's office (as the OWS movement seemed to have understood). The lawyer's office is a place of labour and for that reason, understood as a site of 'circulation' of capital and social production. On the contrary, OWS occupied, symbolically, a park. Here, I argue, rests the kernel of Bartleby's 
misappropriation by the Occupy movement, and the source of Bartleby's actual significance to ongoing political struggle.

Instead of a symbolic occupation, Bartleby passively refuses to perform his tasks, always replying 'I would prefer not to', without leaving the lawyer's office. Rather than merely occupying an office in Wall Street, Bartleby withdraws from his social position, exposing the contingent place in which politics seems to occur. This in turn can be understood as the opening for political subjectivity. But we must then introduce Bartleby to argue that despite never claiming political emancipation, Bartleby's formula itself embodies the political.

At first, Bartleby refuses to examine the copies after the lawyer's request, and subsequently stops copying and performing all office tasks, while also refusing to leave the office premises. For that reason, it is frequently argued that Bartleby neither denies nor affirms, but that his words leave the consequences of his refusal to perform his job in suspension. The story is narrated by the lawyer who describes Bartleby as a 'quiet man', pale and 'pitiably respectable' (Melville, 1990, p.9). The lawyer ignores Bartleby's initial response because he expresses it without a 'wrinkle of agitation' (Melville, 1990, p.10). As the lawyer says, 'had there been the least uneasiness, anger, impatience or impertinence in his manner; in other words, had there been anything ordinarily human about him, doubtless I should have violently dismissed him from the premises' (Melville, 1990, p.10). Bartleby's unwillingness to perform the task for which he is hired is expressed without any resentment or anger but rather in a passive manner. In so doing, he withdraws not only from his socioeconomic position by ceasing to perform his tasks but also from his human qualities through the lack of any emotional expression defining or articulating his course of action. In this sense, it should be noted that despite not defining a single demand towards a political course of action, OWS's attempt to 'represent' the $99 \%$ of the world's population differs from Bartleby's gesture to withdraw from social order.

While trying to make sense of Bartleby's continuous reluctance to examine the copies of the documents, the lawyer keeps asking why he does not perform his task, always receiving 'I would prefer not to' as an answer (Melville, 1990, p.11). Despite his unsuccessful attempts to reason with Bartleby, throughout the story the lawyer gradually grows nervous. Bartleby not only suspends his office tasks but also frustrates the lawyer's desire to get rid of him. When, one Sunday morning, the lawyer visits the office he discovers that Bartleby might have been sleeping and living in the office. He then decides to confront him but Bartleby refuses to engage in conversation, insisting 'I would prefer not to', or changing his formula only slightly to 'at present I prefer to give no answer' or 'at present I would prefer not to be a little reasonable' (Melville, 1990, p.19) when confronted with further questioning. The word 'prefer' ends up contaminating the discourse of the lawyer and his other employees, manifesting itself in their conversations, until Bartleby refuses to copy the documents 
entirely. Despite the contagious power of 'preference', as it reappears in the discourse of the other characters, Deleuze contends that the reason why the formula is important is because it affects Bartleby's performance: the more he says 'I would prefer not to', the more he is incapable of carrying out his task. As a result, the formula renders his function 'impossible'; the source of his refusal, however, remains undetermined (Deleuze, 1998, p.70). A contingency is then created, as Bartleby remains on standby, having suspended his actions but failed to provide alternatives he would 'prefer' to do. He becomes a site of latent possibility; a productive individual removed from the realm of production, and in this sense, from the realm of social order.

When the lawyer visits Bartleby and offers to help him gain a job elsewhere, to facilitate him leaving his office, Bartleby prefers not to change anything. His claims to be "not particular' frustrate the lawyer's attempts to extract enthusiasm from Bartleby towards alternative means of employment (Melville, 1990, p.30). Bartleby has no preference for doing, only a preference for not doing. When confronted with the possibility of taking a new position which would allow him to travel, Bartleby replies that he likes to be 'stationary', preferring 'not to make any change at all' (Melville, 1990, p.30). Such a position exposes the difficulties of seeking a political agency in Bartleby's formula: how is Bartleby's formula political if he appears indifferent to what he prefers? And what might we learn about OWS's own efficacy from this discussion?

Bartleby has been designated as an example of political subjectivity in critical theory (Agamben, 1999a; Deleuze, 1998a; Derrida, 1995; Hardt \& Negri, 2000; Rancière, 2004a; and Žižek, 2006). Each author offers a distinct analysis of Bartleby but they all suggest that his gesture has some capacity for resistance. In 'Bartleby; or the Formula', Deleuze argues that 'I would prefer not to' leaves 'what it rejects undetermined' (1998a, p.68). Whereas, Giorgio Agamben argues that the formula of Melville's character should be understood as a 'pure potentiality' (1999a, p.254) since it suspends a choice between doing something and not doing something. Rancière's 'Deleuze, Bartleby and the Literary Formula' (2004) dialogues directly with Deleuze, while also questioning the formula's capacity for political agency. By recognizing that the formula belongs to the realm of anti-representation, Rancière contends that it seems to guide us only to a contradiction, and as such, it is politically ineffective. This argument is concurrent to Michael Hardt and Antonio Negri's position in Empire (2000), according to which, Bartleby's formula is identified as the beginning of any political emancipation - as a form of negation - but understood to require a positive content presented a posteriori in order to become politically effective. On the contrary, in Parallax View, Žižek argues that Bartleby's formula is the 'underlying principle' (2006, p.382) for all political emancipations, which means that 'I would prefer not to' is inherent to any political struggle rather than merely its starting point. Žižek's disagreement 
with Empire's authors seems to rely on a formal distinction since for him, politics proper is less the 'administration of social matters' than the action of changing 'the framework' in which things are supposed to work (2000, p.199). Finally, Jacques Derrida (1995) argues that Bartleby seems to enact the ultimate ethical gesture by means of suspending a decision.

Because Bartleby is indifferent to what he prefers, his formula can be interpreted as a nihilist move without any consequences in the social and political sphere. However, in order to rescue the formula from absolute nihilism, Deleuze argues that whilst Bartleby prefers 'nothing rather than something', instead of 'a will to nothingness' Bartleby's formula refers to 'the growth of a nothingness of the will' (1998a, p.71). This, in turn, expresses a will without an outcome, or a 'whirling in a suspense' that 'carves out a kind of foreign language within language' (1998a, p.72). In a similar argument, ${ }^{1}$ Agamben contends that Bartleby's formula 'severs language from all reference', opening a 'zone of indistinction' (1999a, p.255). As such, the formula seems to expose the space of encounter between 'the potential to be (or do) and the potential not to be (or do)' (Agamben, 1999a, p.255). In this way, Bartleby's 'I would prefer not to' expresses a non-preference between two terms, since he seems to dwell 'in the abyss of potentiality' without having 'the slightest intention of leaving it' (Agamben, 1999a, p.254). Rather than 'occupying' the site of the possible, Bartleby leaves this very site open, since he remains in the lawyer's office without performing the actions requested from him.

On the other hand, Rancière argues that Bartleby's formula is a performance without a hidden message that breaks with the system of representation. Without any will, Bartleby annihilates 'filial obedience' with a 'radical non-preference' (2004a, p.159) that offers 'the open road of comrades', leading only to a 'contradiction' (2004a, p.164). In this way, Bartleby's formula brings us closer to a suspension rather than sketching an alternative situation and/or a solution. However, the idea of non-affiliation, or of a society without fathers can be understood as a form of rejecting authority and/or a political system that is either framed through totalitarianism, dictatorship, and/or capitalism, here seen as a modern system of power. At the very end of Melville's story, the lawyer interjects 'Ah, Bartleby! Ah, Humanity!' (Melville, 1990, p.34), which again according to Deleuze, suggests the possibility of an alternative order, by exposing the gap between Bartleby and the 'all-toohuman law' (1998, p.81). This so-called 'human law' can be interpreted as a certain state of affairs within capitalism, social representation or even within the symbolic order, depending on one's theoretical position. This also means that suspension, according to Rancière's critique, can be understood as a rejection of a system of power, and in that case, concurrent with Deleuze's argument, Bartleby's formula offers an alternative to the 'all-too-human law' (1998, p.81). 
At the end of the story, the reader is informed that Bartleby used to work at the Dead Letter Office. The Dead Letter Office is the place where the letters that cannot reach their addressee nor be returned to their sender are kept and later destroyed. However, the phrase 'dead letter' also refers to a law or an agreement that is no longer effective. In these terms, in Melville's story, the Dead Letter Office may offer reference to Bartleby's passive acts of refusal; both representing the very procedure posited by Bartleby's formula-the structural inhibition of an outcome or action-and questioning the validity of the 'all-too-human law'.

Rather than recognising the incapacity of Bartleby's formula to provide us with a political outcome, we can recognise that Bartleby's formula seems to cancel the 'device' that enables social order altogether. This, in turn, has a political dimension because politics occurs at the point in which the subject no longer conforms to the social designation that is assigned to him/her. It takes place in the contingent space in which those without a voice claim a place to speak. This is why I argue that Bartleby's formula exposes a space for political contingency.

As argued by Deleuze, Bartleby is 'a pure outsider [...] to whom no social position can be attributed' (1998, p.73). For him, 'Bartleby is the man without references, without possessions, without properties, without qualities, without particularities [...] without past or future, he is instantaneous' (1998, p.74). Bartleby's formula exposes the social interaction between the lawyer and himself and between the lawyer and his clerks, but Bartleby himself cannot fulfil any social position.

Bartleby stops proofreading and copying altogether, claiming that he is 'not particular', which means that he has no preference towards whatever it is that he seems to passively refuse. The narrator tells us that Bartleby has no life outside of work. As such, he is already introduced as an asocial figure but his social role is inherent to his job position. In this manner, by refusing to perform what is expected from him, Bartleby withdraws from his social position. This can be understood as the initial gesture towards emancipation. Bartleby's formula does not put forward a will to political emancipation. Instead it exposes the space through which political emancipation comes into being by pre-empting his place within the social order. Bartleby has no political demands, and instead dies in prison by refusing to eat, as if stripping himself from all forms of subjectivity.

Rather than seeking symbolic interpretation, Deleuze advises the reader of Melville's story to regard Bartleby's formula as 'literal' (1998, p.68). In light of this, we can recognise OWS's appropriation of Bartleby's actions as literal. But to translate his actions as a literal, political move against capitalism is inconsequent because, on the one hand, Bartleby is not occupying symbolically a lawyer's office in Wall Street; and on the other hand, Bartleby's formula itself does not offer a political outcome. Instead, it opens a space of contingency that is inherent to any political struggle. If the formula seems to suggest the pre-empting of a 
social position, then we are indeed, in Bryant's terms, within the realm of a 'cultural and ideological critique of Capitalism' (2011). Rather than political efficacy, Bartleby's formula can only embody the space of a political contingency at the level of signs and discourses. It follows that Bartleby is unwilling to occupy symbolically either a particularity or a universal by preferring 'nothing at all'. Bartleby is neither affirming nor refusing a preference, but instead removing himself from social order. Nevertheless, the formula exposes a contingency that is political since politics occurs at the point in which things and people, senses and thought no longer correspond to their previous allocation and/or understanding, as mentioned before.

Yet another critical reading of Melville's Bartleby may explain the above argument. In The Gift of Death (1995), Jacques Derrida compares Bartleby with the biblical figure of Abraham. This is so because Abraham transgresses the ethical order ${ }^{2}$ since, in the words of Kierkegaard, 'the highest expression of the ethical is in terms of what bind us to our own and to our fellows [...] the actual community' (1995, p.59). When giving an 'account' of one's actions, we 'share' our responsibility. This means that only in silence have we exclusive responsibility for our actions. In this manner, Derrida proposes that responsibility should 'always be expressed in a language foreign to what the community can already hear or understand' (1995, p.74). Derrida's point is concomitant to Deleuze's critique, according to which Bartleby's formula introduces a 'foreign language in language' (1998a, p.72). In a similar argument, Agamben contends that Bartleby's formula 'severs language from all reference' (1999a, p.255). And in the words of Derrida, Abraham 'responds without responding, speaks without saying anything either true or false' (1995, p.74) - just as Bartleby when saying 'I would prefer not to' utters 'nothing fixed, determinable, positive or negative', but something which is left incomplete (Derrida, 1995, p.75). In this way, the formula 'creates a tension: it opens onto a sort of reserve of incompleteness; it announces a temporal or provisional reserve' haunted by the 'silhouette of a content' (Derrida, 1995, p.75).

The connection between Abraham and Bartleby appears in their refusal to comply with the 'law of men' by withdrawing from the community. In both cases, they seem to detach themselves from the community by refusing to give an account for their actions. This is why Derrida's argument can be useful in understanding how Bartleby withdraws simultaneously from the realm of ethics, and from social order. This is also a key point in my argument concerning Bartleby's misappropriation by the occupy movement.

Despite not articulating any form of political emancipation, Bartleby rejects being bound to a community, and it is in this sense that his gesture is political. According to Castronovo, OWS's interpretation of Melville's character has the structure of an analogy. Analogies, as argued, serve to create a common ground between different people, as the means to forge a community. In this way, we can argue that OWS formed an 'alternative community' bound 
by ethical issues. Yet, following Derrida and Deleuze, Bartleby has no social bounds. ${ }^{3}$ Instead, his formula suggests the withdrawal from social order. As such, in terms of the appropriation of Bartleby by OWS, analogy should be rejected because Bartleby's formula offers a space for social contingency through the act of withdrawal, rather than the forging of a social bond. This, in turn, can also be understood in Bryant's terms as a disruption of the nervous system of capitalism, at the level of signs and discourses. But as argued, this disruption is not entirely inconsequent because the reproduction of the capitalist system is also perpetuated through symbolic means. When Bartleby suspends his actions without leaving the lawyer's office he presents himself as an individual removed from the realm of production. However, this gesture is not a symbolic act because the lawyer's office is a site of 'circulation' of capital and social production. In this way, Bartleby's formula not only offers a space for social contingency but also occupies the material infrastructure that sustains the circulatory system of capitalism, which again according to Bryant's argument is the key to the success of the occupy movement. In conclusion, Bartleby's formula has the capacity for political insurgency but it is deprived of a political outcome. This is so because Bartleby has no preference as to what he does prefer to do. Instead, Bartleby suspends his actions and withdraws from social order, resulting in the standstill of social production itself. This, in turn, offers a space for new political subjectivities to emerge in a gesture towards a new community to come. 


\section{Notes}

${ }^{1}$ In conversation with Cesare Casarino, Negri disputes Giorgio Agamben's reading of Bartleby, by also troubling the correspondence between Deleuze and Agamben's theoretical positions. Despite agreeing that potentiality should not be enslaved to actuality, Negri deems actualization indispensable (2008, p.158). Contrary to Agamben, Negri argues that Deleuze 'does not dispense with the "actual"' but instead 'the virtual and the actual form an immanent circuit', while 'the actual always has virtual facets' (2008, p.159). 'The virtual and the actual, thus, are two different ways of apprehending the very same thing'. The actualization of the virtual also 'produces [...] other virtual realities' (2008, p.159). However, in Agamben, 'potentiality always pulls back at the last moment from realizing itself in the act' (2008, p.159). Which means that actualization exhausts potentiality. Here resides, according to Negri, the distinction between Deleuze and Agamben. However, since I draw a parallel between their theoretical arguments, I would like to suggest that Agamben's rescue of potentiality from actuality is concurrent to Deleuze's rescue of the virtual from the actual. This is so, because for Agamben, Bartleby's formula 'has to do exclusively with the occurrence of a potentiality as such, that is, something that can both be and not be', something which is enabled 'by calling into question the principle of the irrevocability of the past, or rather, by contesting the retroactive unrealizability of potentiality' (1999a, p.266). From this perspective, Bartleby's formula seems to question the past, even 'recalling it', not by redeeming 'what was, to make it exist again but, more precisely, to consign it once again to potentiality' (Agamben, 1999a, p.267). In this way, potentiality acquires the function of the virtual, understood here as the surplus of the actual that is capable of redeeming not 'what happened [or] what did not happen but, rather, their potentialization, their becoming possible once again' (Agamben, 1999a, p.267).

2 The ethical order can also be understood as the 'all-too-human law' mentioned above.

3 Following Derrida's argument, Branka Arsić also argues that, 'Bartleby is the name for a being that is not being-with, but being without (with), outside of "social bounds"' (2003, p.156). It is through the figure of Bartleby that Arsic finds an 'affinity', between Deleuze and Derrida's theoretical positions despite their fundamental distinctions. As she puts it, they share an 'affinity [that] precisely because it is affinity, affirms differences' (2003, p.149). The point of convergence between the two philosophers is found in how they both understand Bartleby to be excluded from any social bounds. 


\section{Bibliography}

Agamben, G., 1998. Potentialities: Collected Essays in Philosophy. Edited and translated from Italian by D. Heller-Roazen. Stanford, CA: Stanford University Press.

Arsić, B. Active Habits and Passive Events or Bartleby. In: P. Patton and J. Protevi, eds. 2003. Between Deleuze \& Derrida. London; New York, NY: Continuum. pp. 135-157.

Asher, J., 2013. "Preferring Not To" in the Age of Occupy. The Social Text, [online] 28 March 2013. Available through:

<http://socialtextjournal.org/periscope_article/preferring-not-to-in-the-age-ofoccupy/> [Accessed: 16 March 2015].

Bryant, L., 2011. Onticology and Politics. Larval Subjects, [online] 1 December 2011. Available at: <http://larvalsubjects.wordpress.com/2011/12/o1/onticology-andpolitics/> [Accessed: 27 April 2013].

Casarino, C. and Negri, A., 2008. In Praise of the Common: A conversation on Philosophy and Politics. Minneapolis, MN; London: University of Minnesota Press.

Castronovo, R., 2014. Occupy Bartleby. J19 The Journal of Nineteenth-Century Americanists, 2(2), pp. 253-272.

Coetzee, J.M., 1985. The Life and Times of Michael K. London: Penguin Books.

Deleuze, G., 1998. Bartleby, or the Formula. Essays: Critical and Clinical. Translated from French by D.W. Smith and M.A. Greco. London; New York, NY: Verso. pp. 68-90.

Derrida, J., 1995. The Gift of Death. Chicago, IL; London: The University of Chicago Press.

Douglas, B., 2015. Rio 2016: Occupy takes swing at Olympic golf course. The Guardian, [online] 25 February 2015. Available at:

<http://www.theguardian.com/world/2015/feb/25/rio-2016-occupy-takes-swing-atolympic-golf-course > [Accessed: 16 March 2015].

Gambino, L., 2014. St Louis activists interrupt Black Friday shopping to stage Michael Brown protest. The Guardian, [online] 28 November 2014. Available at: <http://www.theguardian.com/us-news/2014/nov/28/st-louis-black-friday-protest> [Accessed: 16 March 2015]. 
Greenberg, J.D., 2012. Occupy Wall Street's Debt to Melville. The Atlantic, [online] 30 April 2012. Available at: <http://www.theatlantic.com/politics/archive/2012/o4/occupywall-streets-debt-to-melville/256482/> [Accessed: 16 March 2015].

Hardt, M. and Negri, A., 2000. Empire. Cambridge, MA; London: Harvard University Press.

Hedgecoe, G., 2015. Yes we can: Spain's Podemos party leads electoral pack. Aljazeera America, [online] 12 February 2015. Available at: $<$ http://america.aljazeera.com/articles/2015/2/12/spain-podemos-party-leadselectoral-pack.html> [Accessed: 16 March 2015].

Klein, L., 2011. What Bartleby Can Teach Us About Occupy Wall Street. Arcade: Literature, the Humanitites, and the World, [online]. 21 November 2011. Available at: <http://arcade.stanford.edu/blogs/what-bartleby-can-teach-us-about-occupy-wallstreet> [Accessed: 27 April 2013].

Lacan, J., 1972. Seminar on "The Purloined Letter". Yale French Studies/Jstor. pp. 39-72.

Martyris, N., 2011. A Patron Saint for Occupy Wall Street. New Republic, [online]. 15 October 2011. Available from: <http://www.newrepublic.com/article/politics/96276/nina-martyris-ows-andbartleby-the-scrivener $>$ [Accessed: 27 April 2013].

Melville, H., 1990. Bartleby the Scrivener. New York: Dover Publications Inc.

Rancière, J., 2004a. Deleuze, Bartleby and the Literary Formula. The Flesh of Words: The Politics of Writing. Translated from French by C. Mandell. Stanford, CA: Stanford University Press. pp. 146-164. 2004b. The Politics of Aesthetics: The Distribution of the Sensible. Translated from French by G. Rockhill. London and New York: Continuum. 2008. The Emancipated Spectator. Translated from French by G. Elliot. London; New York: Verso. 2010. Dissensus: On Politics and Aesthetics. Edited and translated from French by S. Corcoran. London; New York: Continuum.

Steyeri, H., 2012. The Spam of the Earth: Withdrawal from Representation. E-flux, [online]. 32, February 2012. pp. 1-9. Available through: <http://www.e-flux.com/journal/thespam-of-the-earth/> [Accessed: 7 May 2012].

Yin, M., 2011. 'Bartleby, The Scrivener' Reading at Occupy Wall Street. Media Bistro, [online] 11 November 2011. Available at: 
<http://www.mediabistro.com/galleycat/bartleby-the-scrivener-reading-at-occupywall-street_b42052> [Accessed: 27 April 2013].

Žižek, S., 2000. The Ticklish Subject. The Absent Centre of Political Ontology. London; New York: Verso.

2006. The Parallax View. Cambridge; London: MIT Press.

2008. Enjoy Your Symptom!: Jacques Lacan in Hollywood and Out. New York; London: Routledge Classics. 